4541.

[15] G-S. Elizabeth, S. Giannoutsos, D.R. Lower, M.A. Virji, M.D. Krasowski, J. Chromatogr. Sci. 45 (2007) 9616.

[16] Z.K. Shihabi, K.S. Oles, J. Chromatogr. B, Biomed Appl. $683(1996) 119$.

[17] R. Theurillat, M. Kuhn, W. Thormann, J. Chromatogr. A. 979 (2002) 353.

[18] R.A. Biddlecombe, K.L. Dean, C.D. Smith, S.C. Jeal,. J. Pharm. Biomed. Anal. 8 (1990) 691

[19] J.M. Sailstad. J.W.A. Findlay, Ther. Drug. Monit., 13 (1991) 433.

[20] R.S. Talekar, A.S.Dhake, D.B. Sonaje, V.K. Mourya, Ind. J. Pharm. Sci. 62 (2000) 51.

[21] D-R. Olga, M.E Calvo, M. Acros-Martinez, J.. Sensors. 8 (2008) 4201; DOI:10.3390/s807420

[22] N. Rahman, S.N. Hejaz-Azmi, J. Pharm. Biomed. Anal. $24(2000) 33$.

[23] N. Silva, E.E.S. Schapoval, J. Pharm. Biomed. Anal. 29 (2002) 749.

[24] T. Perez-Ruiz, C. Martinez-Lozano, V. Tomás, A. Sanz, E. Sauquillo, J. Pharm. Biomed. Anal. 26 (2001) 609.

[25] K. Basavaiah, V.S. Charan, LL Farmaco. 57 (2002) 9.

[27] H. Fagson, H. Yawya-saeb, A. Fawzy, Int, J. Ph 32.7 (1981) 343 . H. Ya

[28] A.S. Douglas, M.W. Donald. "Principels of Instrumental Analysis," Holt, Rinhart and Winston, New York, 1971.pp. 104.

[29] N. Erk. Anal. Lett. 36 (2003) 1183.

[30] H. Zavis, D. Ludvik, K. Milan, S. Ladislaw, V. Frantisck, Handbook of Organic Reagents in Inorganic Analysis. Translated by Stanislav, K, Dr. Chalmers (The Series and Translation Editor: University of Aberdem, Ellis Horwood Limited, Chichester, A Division of John Wiley \& Sons IC, New York, London, Sydney, Toronto. 1976. pp.364.

[31] International Conference on Hormonisation of Technical Requirements for Registration of Pharmaceuticals for Humal Use, ICH Harmonised Tripartite Guideline, Validation of Analytical Procedures: Text and Methodology Q2(R 1).Complementary Guideline on Methodology dated 06 November 1996, incorporated in November 2005, London.

[32] J. Inczedy, T. Lengyel, A.M. Ure,. IUPAC Compendium of Analytical Nomenclature : 1998. Definitive Rules, Blackwell Science Inc., Boston.

\title{
COMPLEXES OF 4-CHLOROPHENOXYACETATES OF ND(III), GD(III) AND HO(III)
}

W.Ferenc ${ }^{*}$, M.Bernat ${ }^{l}$, J.Sarzyński ${ }^{2}$ and H.Gluchowska 'Faculty of Chemistry, Maria Curie-Sklodowska University, PL 20-031 Lublin, Poland

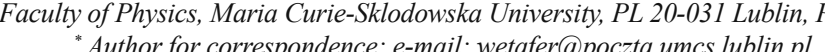

Abstract: The complexes of 4-chlorophenoxyacetates of Nd(III), Gd(III) and Ho(III) have bee synthesized as polycrystalline hydrated solids, and characterized by elemental analysis, spectroscopy, magnetic studies and also by X-ray diffraction and thermogravimetric measurements. The analysed complexes have the following colours: violet for $\mathrm{Nd}(\mathrm{III})$, white for $\mathrm{Gd}(\mathrm{III})$ and cream for $\mathrm{Ho}$ (III) compounds. The carboxylate groups bind as bidentate chelating (Ho) or bridging ligands $(\mathrm{Nd}, \mathrm{Gd})$. On heating to $1173 \mathrm{~K}$ in air the complexes decompose in severa steps. At first, they dehydrate in one step to form anhydrous salts, that next decompose to the oxides of respective metals. The gaseous products of their thermal decomposition in nitrogen were also dective and the magnetic susceptibilites were mesured over the temperat rophenoxyacetates of $\mathrm{Nd}(\mathrm{III}), \mathrm{Gd}(\mathrm{III})$ and $\mathrm{Ho}(\mathrm{HI})$ are high-spin compexes with weak ligand fields. The solubility value in water at $293 \mathrm{~K}$ for analysed 4-chlorophenoxyacetates is in the order of $10^{-4} \mathrm{~mol} / \mathrm{dm}^{3}$

Keywords: 4-chlorophenoxyacetates, thermal stability, magnetic properties of $\mathrm{Nd}(\mathrm{III}), \mathrm{Ho}(\mathrm{III})$ and $\mathrm{Gd}(\mathrm{III})$.

\section{Introduction}

The carboxylates play an important role in norganic and bioinorganic chemistry. Many metal cations are a component of several vitamins and drugs $[1,2]$. The carboxylates of $\mathrm{d}$ and $4 \mathrm{f}$ and elements may be use as electic modern branches of techiques and technology. They may have also applications as precursors in superconducting ceramic and magnetic field productions and may be used as catalysts, pigments, solvents, food preservatives and plastics produc tions.

Metal carboxylates are applied for the productions of high degree purity of metal oxides and polycarboxylic acids are used for supermolecular with metal ions the molecular polymers containing in their structures, pores and channels owning to them they appear catalytic and adsorption properties. Therefore they may be used for the adsorption of inorganic gases such as: argon, nitrogen and hydrocarbons or small molecules of anothe inorganic compounds. Polycarboxylic acids may also form the molecules with two- and three-dimentional structures, yielding special magnetic and luminescence properties which let them be used in optical and electronic industries [3-10]. 4 -Chlophenoxy id hardly soluble in soluble soluble in water $\left(\mathrm{K}=7,9 \cdot 10^{4}\right)$ and easily soluble in ether and ethanol $[10,11]$. It is used as growth hormone for plants [12]. In some papers the details of its molecular structure was presented [13-15]. Literature survey informs that its complexes with Li(I), Cu(II), Co(II), Mn(II) and 
$\mathrm{Ni}(\mathrm{II})$ ions were synthesized and their properties were studied $[10,16,17]$.

As a continuation of our studies on chlorophenoxyacetates and also on carboxylates $[10,18$ 30] we decided to synthesized 4-chlorophenoxyacetates with $\mathrm{Nd}(\mathrm{III}), \mathrm{Gd}(\mathrm{III})$ and $\mathrm{Ho}(\mathrm{III})$ and to study some of those of their properties not to have been investigated so far, such as magnetic properties in the range of $76-303 \mathrm{~K}$, thermal stability in air at $293-1173 \mathrm{~K}$, solubility in water at $293 \mathrm{~K}$ and to record their FTIR spectra.

Thermal stability investigations give informations about the process of dehydration about the ways of decompositions, and the magnetic susceptibility measurements let study the the maner of cental ion coordination. The dethe mintion of the solubility is valuable becouste inforton of the solubility is valuable because it informs about the practical use of acid for se-
paration of transition metal ions by extraction or paration of transition metal ions by extract
ion-exchange chromatographic methods.

Table 1. Elemental analysis data of $\mathrm{Nd}(\mathrm{III}), \mathrm{Gd}(\mathrm{III})$ and $\mathrm{Ho}(\mathrm{III})$ 4-chlorophenoxyacetates and their solubility in water at $293 \mathrm{~K}$.

\begin{tabular}{cccccccccc}
\hline \multirow{2}{*}{ Complex L- $=\mathrm{C}_{8} \mathrm{H}_{6} \mathrm{ClO}_{3}$} & \multicolumn{2}{c}{$\mathrm{H} / \%$} & \multicolumn{2}{c}{$\mathrm{C} / \%$} & \multicolumn{2}{c}{$\mathrm{Cl} \%$} & \multicolumn{2}{c}{$\mathrm{M} / \%$} & \multicolumn{2}{c}{ Solubility } \\
calcd & found & calcd & found & calcd & found & calcd & found & $\mathrm{mol} \cdot \mathrm{dm}^{-3}$ \\
\hline $\mathrm{NdL}_{2} \cdot 2 \mathrm{H}_{2} \mathrm{O}$ & 3.00 & 2.77 & 39.10 & 38.96 & 14.50 & 14.48 & 19.60 & 22.70 & $5,3 \cdot 10^{-4}$ \\
$\mathrm{GdL}_{3} \cdot 2 \mathrm{H}_{2} \mathrm{O}$ & 2.90 & 2.79 & 38.40 & 38.94 & 14.20 & 14.18 & 20.90 & 19.50 & $7,6 \cdot 10^{-4}$ \\
$\mathrm{HoL} \cdot 3 \mathrm{H}_{2} \mathrm{O}$ & 3.10 & 2.88 & 37.10 & 37.16 & 14.10 & 14.08 & 21.80 & 21.20 & $8,5 \cdot 10^{-4}$ \\
\hline
\end{tabular}

The contents of $\mathrm{M}^{3+}$ were established gravimetrically and by XRF method using spectrometer of X-ray fluorescence with energy dispersion EDXRF-1510 (CANBERRA firm).

The IR and FIR spectra of complexes were recorded over the ranges $4000-400 \mathrm{~cm}^{-1}$ and 600 $100 \mathrm{~cm}^{-1}$, respectively, using M-80 and Perkin-Elmer 180 spectrometers. Samples for IR spectra measurements were prepared as $\mathrm{KBr}$ discs. FIR spectra were obtained in Nujol mulls sandwiched between polyethylene plates (Table 2)

The FTIR spectra of the intermediate and final products obtained from the complex thermal decompositions were also registered.
The 4-chlorophenoxyacetates of $\mathrm{Nd}(\mathrm{III})$ f ot solutions containing the $0,1 \mathrm{~mol} \cdot \mathrm{dm}^{-3} \mathrm{Nd}(\mathrm{III})$ t $293 \mathrm{~K}$ (1h) (Ih) nitrates (V) and crystallizing (n) complexes and in the intermediate and final proCHN 2500 Perin by elemental analysis using a CHN 2500 Perkin-Elmer analyzer and the content of chlorine by the Schöniger method (Table 1).
Table 2. Wavenumbers $\left(\mathrm{cm}^{-1}\right)$ of $\mathrm{COO}^{-}$bands in the analysed complexes of $\mathrm{Nd}(\mathrm{III}), \mathrm{Gd}(\mathrm{III}), \mathrm{Ho}(\mathrm{III})$, and $\mathrm{Na}(\mathrm{I})$, and that of the $\mathrm{COOH}$ band in 4-chlorophenoxyacetic acid.

\begin{tabular}{ccccccc}
\hline Complex $\mathrm{L}-=\mathrm{C} 8 \mathrm{H} 6 \mathrm{ClO} 3$ & ${ }^{v} \mathrm{C}=\mathrm{O}$ & ${ }^{v}$ as $\mathrm{OCO}$ & ${ }^{v}$ sym OCO & ${ }^{\Delta v} \mathrm{OCO}$ & ${ }^{v} \mathrm{C}-\mathrm{Cl}$ & ${ }^{v} \mathrm{M}-\mathrm{O}$ \\
\hline $\mathrm{NdL}_{3} \cdot 2 \mathrm{H}_{2} \mathrm{O}$ & - & $1^{567}$ & $1^{335}$ & $2^{33}$ & $5^{07}$ & $4^{51}$ \\
$\mathrm{GdL}_{3} \cdot 2 \mathrm{H}_{2} \mathrm{O}$ & - & 1572 & 1337 & 235 & 507 & 452 \\
$\mathrm{HoL}_{3} \cdot 3 \mathrm{H}_{2} \mathrm{O}$ & - & 1572 & 1346,1328 & 226,244 & 528,503 & 449 \\
${ }_{\mathrm{H}}^{\mathrm{L}}$ & 1708 & - & - & - & 722 & - \\
$\mathrm{NaL}$ & - & 1615 & 1344 & 271 & 722 & 449 \\
\hline
\end{tabular}

The X-ray diffraction patterns of hydrated and dehydrated complexes, the intermediate and final products of complex thermal decompositions were taken on a HZG-4 (Carl Zeiss Jena) diffractometer using Ni filtered $\mathrm{Cu} \mathrm{K} \alpha$ radiation. The measurements were made within the range $2 \Theta=4-80^{\circ}$ by mean of the Debeye-Scherrer-Hull method. The relationships between $\mathrm{I} / \mathrm{I}$ and $2 \Theta$ for these complexes are presented in Fig.1.

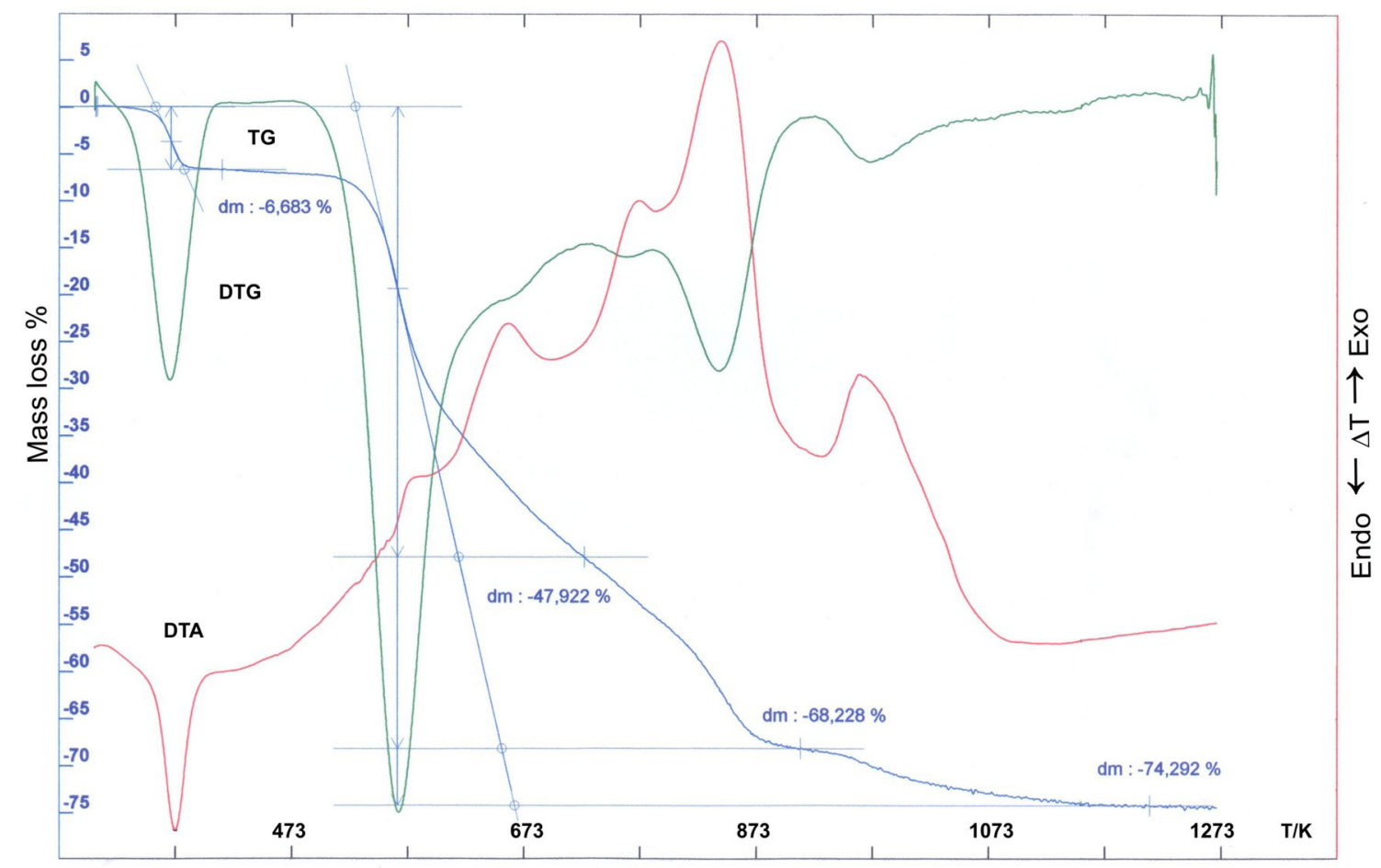

Fig. 1. Dependence of I/Io $v s 2 \theta$ for $\mathrm{Nd}(\mathrm{III}), \mathrm{Gd}(\mathrm{III})$ and $\mathrm{Ho}(\mathrm{III})$ 4-chlorophenoxyacetates.

The thermal stability and decomposition of the prepared complexes were determined by Paulik-Paulik-Erday Q-1500D derivatograph with Derill converter, recording TG, DTG, and DTA curvers (Fig.2). The measurements were made at a heating rate of $10 \mathrm{~K} \mathrm{~min}^{-1}$ with a full scale. The samples $(100 \mathrm{mg})$ were heated in platinum crucibles in static air to $1173 \mathrm{~K}$ with a sensitivity of TG-100mg. DTG and DTA sensitivities were regulated by a Derill computer program. The products of decompositio

Ecl. Quím., São Paulo, 35(1): 67 - 75, 2010 
were calculated from TG curves and verified by the diffraction pattern registration and IR spectra. The termogravimetric analysis of DSC/TG was performed at temperature 323-723K using a differential thermoanalyzer Netzsch STA 409C 3F. The measurements were carried out under nitrogen flow $(99,995 \%$ purity) and temperature increase rates of $1-12 \mathrm{~K} \mathrm{~min}^{-1}$

Table 3. Temperature ranges of thermal stability of $\mathrm{Nd}(\mathrm{III})$, $\mathrm{Gd}(\mathrm{III})$ and $\mathrm{Ho}(\mathrm{III})$ 4-chlorophenoxyacetates in air.

\begin{tabular}{|c|c|c|c|c|c|c|c|c|c|c|c|c|c|c|}
\hline \multirow{2}{*}{$\begin{array}{c}\text { Complex } \\
\mathrm{L}= \\
\mathrm{C}_{8} \mathrm{H}_{6} \mathrm{ClO}_{3}\end{array}$} & \multirow[t]{2}{*}{$\Delta \mathrm{T}_{1} / \mathrm{K}$} & \multicolumn{2}{|c|}{ Mass loss $\%$} & \multirow[t]{2}{*}{$\mathrm{n}_{2} \mathrm{O}_{2}$} & \multirow[t]{2}{*}{$\Delta \mathrm{T}_{2} \mathrm{~K}$} & \multicolumn{2}{|c|}{ Mass loss $\%$} & \multirow[t]{2}{*}{$\begin{array}{l}\text { Intermedate } \\
\text { product }\end{array}$} & \multirow[t]{2}{*}{$\underset{\left.\mathrm{kJ} \cdot \mathrm{mol}\right|^{\mathrm{H}}}{\Delta \mathrm{H} /}$} & \multirow[t]{2}{*}{$\begin{array}{l}\Delta H_{1 H_{1} O} \\
\text { kJ } \mathrm{J} \cdot \mathrm{mol}^{-1}\end{array}$} & \multirow[t]{2}{*}{ TKK } & \multicolumn{2}{|c|}{$\begin{array}{l}\text { Mass of } \\
\text { residuel\% }\end{array}$} & \multirow[t]{2}{*}{$\begin{array}{c}\text { Final } \\
\text { product of } \\
\text { decomposition }\end{array}$} \\
\hline & & calcd. & found & & & calcd & found & & & & & calcd & found & \\
\hline${ }_{3}+\mathrm{H}_{2} \mathrm{U}$ & $338-416$ & 4,34 & 4,88 & 2 & $\begin{array}{l}55 \\
87\end{array}$ & 73,45 & 72,14 & & 90,8 & & 1273 & 22,80 & $\sim 23,3$ & $\mathrm{Nd}_{2} \mathrm{O}_{3}$ \\
\hline & & 4,27 & 4,81 & 2 & $\begin{array}{l}573- \\
923\end{array}$ & 72,18 & 71,42 & & & & 1270 & 24,30 & $\sim 24,0$ & \\
\hline $\mathrm{HOL}_{3}^{3} 3 \mathrm{H}_{2} \mathrm{O}$ & $312-425$ & 6,96 & 6,68 & 3 & $\begin{array}{l}573- \\
912\end{array}$ & 70,20 & 68,22 & HoOCl & 156,8 & 52,3 & 1223 & 24,27 & 24,3 & $\mathrm{H}_{2} \mathrm{O}_{3}$ \\
\hline
\end{tabular}

$\Delta \mathrm{T}_{1}$ - temperature range of dehydration process, $\Delta \mathrm{T}_{2}-$ temperature range of anhydrous complex decomposition, $\mathrm{n}$ - number of water molecules lost in the one step of dehydration process, $\Delta \mathrm{H}$ - enthalpy value of dehydration process, $\mathrm{T}_{\mathrm{K}}$ - final temperature of decomposition process, $\Delta \mathrm{H}_{1 \mathrm{H}_{2} \mathrm{O}}$ - enthalpy value for one molecule of water, $\mathrm{T}_{\mathrm{K}}$ - final temperature of decomposition process

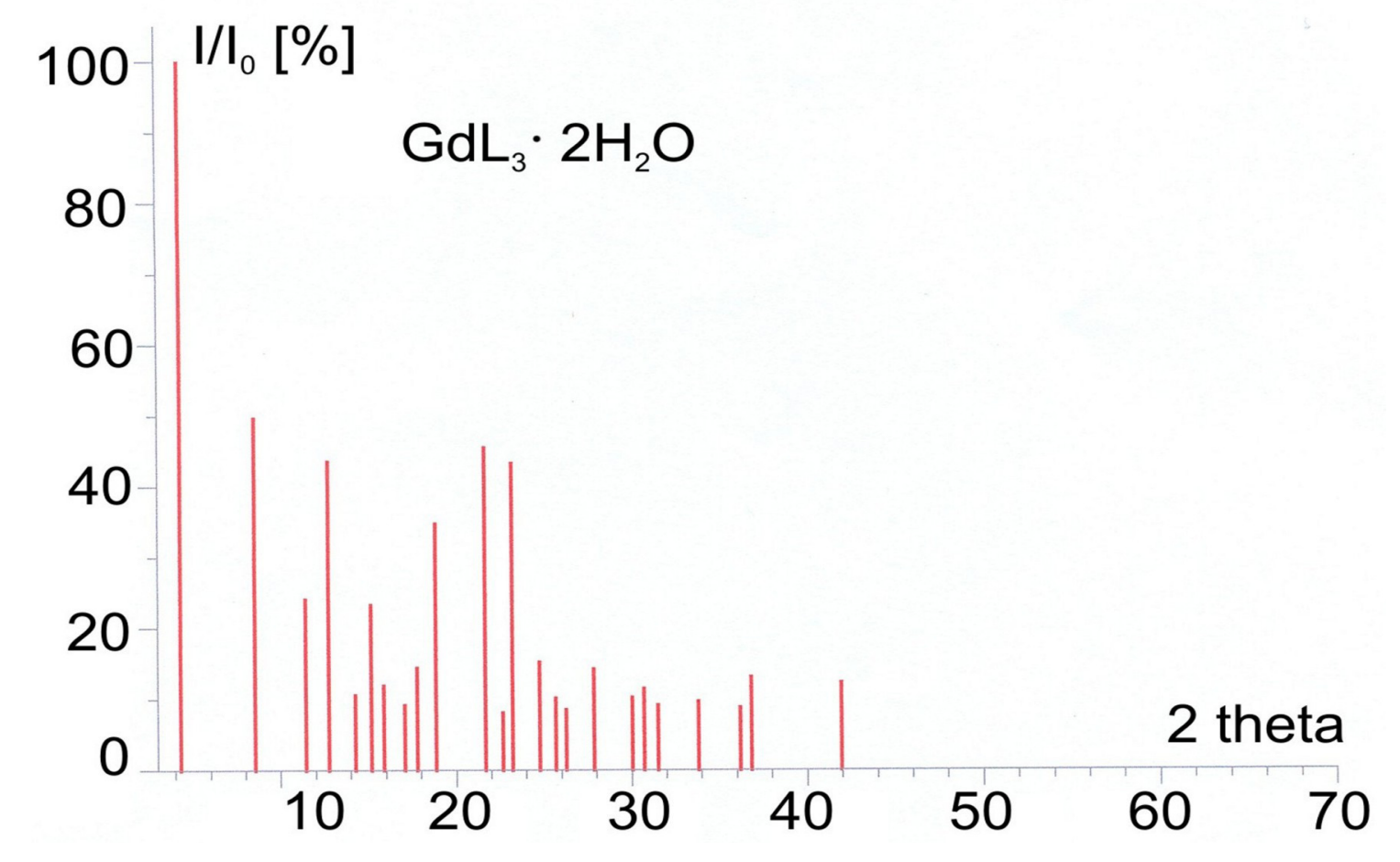

Fig. 2. TG,DTG and DTA curves for Ho(III) 4-chlorophenoxyacetate in air
Magnetic susceptibilities of polycrystalline samples of 4-chlorophenoxyacetates of $\mathrm{Nd}(\mathrm{III})$, $\mathrm{Gd}(\mathrm{III})$ and $\mathrm{Ho}(\mathrm{III})$ were measured by the Gouy method using a sensitive Cahn RM-2 balance. The samples were placed in a long cylindrical tube sanples were placed in a long cylyical balace. which was suspended from an analytical balance. The sample tube was positioned between the poles of the magnet such that one its end was in the region of homogenous field and the other end was in the region of zero field. The force exerted on the sample was a function of the volume occupied by

the sample in the region of the field gradient. This force may be written in scalar form as a function of the isotropic volume susceptibility. Measurements were carried out at a magnetic field strength of 9,9 kOe. The calibrant employed was $\mathrm{Hg}\left[\mathrm{Co}(\mathrm{SCN})_{4}\right]$ for which the magnetic susceptibility was assumed to be $1,644 \cdot 10^{-5} \mathrm{~cm}^{3} \mathrm{~g}^{-1}$. Correction for diamagnetism of the calibrant atoms was calculated by the use of Pascal's constants [31,32]. Magnetic moments were calculated from Eq.(1):

$\mu_{\text {eff }}=2,83\left(\chi_{\mathrm{M}} \cdot \mathrm{T}\right)^{1 / 2}$

Table 4. Magnetic data for the studied complexes of $\mathrm{Nd}(\mathrm{III}), \mathrm{Gd}(\mathrm{III})$ and $\mathrm{Ho}(\mathrm{III}), \mathrm{L}^{-}=\mathrm{C}_{8} \mathrm{H}_{6} \mathrm{ClO}_{3}$.

\begin{tabular}{ccccccccc}
\hline & $\begin{array}{c}\mathrm{NdL}_{3} \cdot 2 \mathrm{H}_{2} \mathrm{O} \\
\theta=-25\end{array}$ & \multicolumn{3}{c}{$\begin{array}{c}\mathrm{GdL}_{3} \cdot 2 \mathrm{H}_{2} \mathrm{O} \\
\theta=-8,2\end{array}$} & & \multicolumn{3}{c}{$\begin{array}{c}\mathrm{HoL}_{3} \cdot 3 \mathrm{H}_{2} \mathrm{O} \\
\theta=-35\end{array}$} \\
\hline $\mathrm{T} / \mathrm{K}$ & $\chi_{\mathrm{M}} \cdot 10^{6}$ & $\mu_{\text {eff }} / \mu_{\mathrm{B}}$ & $\mathrm{T} / \mathrm{K}$ & $\chi_{\mathrm{M}} \cdot 10^{6}$ & $\mu_{\mathrm{eff}} \mu_{\mathrm{B}}$ & $\mathrm{T} / \mathrm{K}$ & $\chi_{\mathrm{M}} \cdot 10^{6}$ & $\mu_{\text {eff }} / \mu_{\mathrm{B}}$ \\
\hline 76 & 14292 & 2.95 & 76 & 97416 & 7.70 & 76 & 166685 & 10.07 \\
123 & 9964 & 3.13 & 123 & 60763 & 7.74 & 123 & 106935 & 10.26 \\
133 & 9335 & 3.15 & 133 & 55865 & 7.71 & 133 & 98520 & 10.24 \\
143 & 8763 & 3.17 & 143 & 51821 & 7.70 & 143 & 91856 & 10.26 \\
153 & 8343 & 3.20 & 153 & 48289 & 7.69 & 153 & 87225 & 10.34 \\
163 & 7924 & 3.22 & 163 & 45099 & 7.67 & 163 & 81917 & 10.34 \\
173 & 7543 & 3.23 & 173 & 42622 & 7.68 & 173 & 77229 & 10.34 \\
183 & 7237 & 3.26 & 183 & 40172 & 7.67 & 183 & 73389 & 10.37 \\
193 & 7009 & 3.29 & 193 & 38435 & 7.71 & 193 & 69831 & 10.39 \\
203 & 6742 & 3.31 & 203 & 36669 & 7.72 & 203 & 66386 & 10.39 \\
213 & 6418 & 3.31 & 213 & 34733 & 7.70 & 213 & 63506 & 10.41 \\
223 & 6189 & 3.32 & 223 & 33252 & 7.71 & 223 & 60683 & 10.41 \\
233 & 5960 & 3.33 & 233 & 31771 & 7.70 & 233 & 57972 & 10.40 \\
243 & 5769 & 3.35 & 243 & 30518 & 7.71 & 243 & 55713 & 10.41 \\
253 & 5636 & 3.38 & 253 & 29293 & 7.70 & 253 & 53680 & 10.43 \\
263 & 5445 & 3.39 & 263 & 28467 & 7.74 & 263 & 51985 & 10.46 \\
273 & 5274 & 3.40 & 273 & 27470 & 7.75 & 273 & 51082 & 10.57 \\
283 & 5178 & 3.43 & 283 & 26701 & 7.78 & 283 & 49049 & 10.54 \\
293 & 5083 & 3.45 & 293 & 25933 & 7.80 & 293 & 47693 & 10.58 \\
303 & 4949 & 3.47 & 303 & 25192 & 7.82 & 303 & 45943 & 10.56 \\
\hline
\end{tabular}

The solubilities of 4-chlorophenoxyacetates of $\mathrm{Nd}(\mathrm{III}), \mathrm{Gd}(\mathrm{III})$ and $\mathrm{Ho}(\mathrm{III})$ in water were measured at $293 \mathrm{~K}$. Saturated solutions of the obtained compounds were prepared under isothermal conditions. The contents of $\mathrm{Nd}(\mathrm{III}), \mathrm{Gd}(\mathrm{III})$ and $\mathrm{Ho}(\mathrm{III})$ were determined using ASA 880 spectrofotometer (Varian). The values of solubilics are presented in Table1.

\section{Results and Discussion}

The complexes of 4-chlorophenoxyacetates of $\mathrm{Nd}(\mathrm{III}), \mathrm{Gd}(\mathrm{III})$ and $\mathrm{Ho}(\mathrm{III})$ were obtained as polycrystalline products with a metal ion to ligand ratio of $1: 3$ and the general formula $\mathrm{M}\left(\mathrm{C}_{8} \mathrm{H}_{6} \mathrm{ClO}_{3}\right)_{3}$. $\mathrm{nH}_{2} \mathrm{O}$, where $\mathrm{M}(\mathrm{III})=\mathrm{Nd}$, Gd, Ho and $\mathrm{n}=2$ for $\mathrm{Nd}$ and $\mathrm{Gd}$ and $\mathrm{n}=3$ for Ho.Their colours are following: violet for $\mathrm{Nd}(\mathrm{III})$, cream for $\mathrm{Ho}(\mathrm{III})$, and 
white for $\mathrm{Gd}(\mathrm{III})$ complexes. In these compounds the $\mathrm{f} \rightarrow \mathrm{f}$ electron transitions of the central ions are those of the lowest energy and absorption occurs at relatively high wave lengths that depends on the nature of the metal ion $[33,34]$

The compounds were characterized by elemental analysis (Table 1), FTIR and FIR spectra (Table 2).

The 4-chlorophenoxyacetates of $\mathrm{Nd}(\mathrm{III})$, Gd(III) and Ho(III) exhibit similar solid state IR spectra. The band at $1708 \mathrm{~cm}^{-1}$ originating from the $\mathrm{RCOOH}$ group, presented in the acid spectrum, is replaced in the spectra of complexes by two bands at $1572-1567 \mathrm{~cm}^{-1}$ and $1346-1328 \mathrm{~cm}^{-}$ 1, which can be ascribed to the asymmetric and symmetric vibrations of $\mathrm{COO}^{-}$group, respectively [35-38].

The bands with the maxima at 3429$3410 \mathrm{~cm}^{-1}$ characteristic for $v_{\mathrm{OH}}$ vibrations [35-40] confirm the presence of crystallization water molecules in the complexes.

The bands of $\mathrm{C}-\mathrm{H}$ vibrations are observed at $2929-2918 \mathrm{~cm}^{-1}$. The bands of $v(\mathrm{C}=\mathrm{C})$ ring vibrations appear at $1624-1622 \mathrm{~cm}^{-1}, 1494 \mathrm{~cm}^{-1}$, $1177-1174 \mathrm{~cm}^{-1}, 1111-1104 \mathrm{~cm}^{-1}$ and $1068-1066 \mathrm{~cm}^{-}$ ${ }^{1}$.The valency $v(\mathrm{C}-\mathrm{Cl})$ vibration bands occur at $734-730 \mathrm{~cm}^{-1}$ and those of the asymmetric and symmetric $v(\mathrm{C}-\mathrm{O}-\mathrm{C})$ at $1082-1068 \mathrm{~cm}^{-1}$ and 1060 $1058 \mathrm{~cm}^{-1}$, respectively. The bands at $451-449 \mathrm{~cm}^{-}$ ${ }^{1}$ confirm the ionic metal-oxygen bond [41-50]. These bands change insignificantly their positions which may suggest the different stability of these complexes.

The bands in the range of $118-106 \mathrm{~cm}^{-1}$ are and they change their shapes according to the rise of atomic in 4-chlorophenoxyacetates. The bands at $138-122 \mathrm{~cm}^{-1}$ confirm the internal C-C torsion vibrations and the bands at $283-267 \mathrm{~cm}^{-1}$ arising from the aromatic ring vibrations also change their shapes.

Table 2 presents the values of the two band frequencies of asymmetrical and symmetrical vibrations for carboxylate group of analysed complexes.

The separations of the $v_{\text {as }}\left(\mathrm{COO}^{-}\right)$, and $v_{s}\left(\mathrm{COO}^{-}\right)$modes in the compounds, $\Delta v\left(\mathrm{COO}^{-}\right)$, are smaller than that of the sodium salt $\left(\Delta v_{\text {COO- }}=\right.$
$271 \mathrm{~cm}^{-1}$ ) indicating a smaller degree of $\mathrm{M}-\mathrm{O}$ ionic bonds in 4-chlorophenoxyacetates compared to that of the sodium salt. For the complexes the shifts of the frequencies of bands of $v\left(\mathrm{COO}^{-}\right)$ as $v_{(\mathrm{COO})}$ ) are lower, (hame, , noxyacetate. Accordingly, taking into account the pectroscopic criteria $[36-38,49,51]$ the carboxy ions appear to be bidentate groups.

In order to estimate the crystalline forms of the 4-chlorophenoxyacetates the X-ray powder diffraction measurements were done. The diffractogram values suggest them to be polycrystalline compounds with various degree of crystallinity [52] (Fig.

The thermal stability of $\mathrm{Nd}(\mathrm{III}), \mathrm{Gd}(\mathrm{III})$ and $\mathrm{Ho}(\mathrm{III})$ ) 4-chlorophenoxyacetates was studied in air at 293-1273K (Table 3. Fig.2)

When heated to $1273 \mathrm{~K}$ the $\mathrm{Nd}$ (III) complex is dehydrated in one step. In the temperature rang of $338-416 \mathrm{~K}$ it losses two water molecules and forms anhydrous salt. The loss of mass calculated from TG curve is equal to $4,88 \%$ (theoretical value is 4,34\%). The anhydrous salt at $553-1273 \mathrm{~K}$ is gradually decomposed to $\mathrm{Nd}_{2} \mathrm{O}$ that is the final product of complex decomposition. The intermediate compond for din pect 作 and the cadculated value $73,45 \%$. The residue mas estimated from TG curve is equal to $23,27 \%$ while that theoretically calculated $22,80 \%$. The dehydration process is connected with endothermic effect whereas the combustion of the organic ligand is accompanied by exothermic one. The final product of complex decomposition was confirmed by IR spectra and X-ray powder diffractogram.

The dihydrate of $\mathrm{Gd}(\mathrm{III})$ 4-chlorophenoxyacetate during heating in air losses the water molecules in one stage in the range of $316-412$ $\mathrm{K}$ and forms anhydrous salt. The final product of complex decomposition was identified by elemenal analysis and X-ray powder diffractogram a $\mathrm{Gd}_{2} \mathrm{O}_{3}$. The intermediate product of complex decomposition is $\mathrm{GdOCl}$ formed at $573-923 \mathrm{~K}$. The found weight loss is equal to 71,42 and calculated one $72,18 \%$. The residue mass estimated from TG curve is $24,0 \%$ and theoretically determined $24,30 \%$. The dehydration process is connected with the endoeffect while that of oxidation with exothermic one.

When heated in air to $1173 \mathrm{~K}$ the trihydrate of 4-chlorophenoxyacetate of $\mathrm{Ho}(\mathrm{III})$ dehydrates in one step at $312-425 \mathrm{~K}$ and forms anydrous in one sep at $312-425 \mathrm{~K}$ and for salt. The mass loss calculated from Ta curve being equal to $6,68 \%$ corresponds to the loss of thre molecules of water (theoretical value is equal to $6,96 \%)$. The anhydrous 4-chlorophenoxyacetate of $\mathrm{Ho}(\mathrm{III})$ at $573-1223 \mathrm{~K}$ is decomposed to $\mathrm{Ho}_{2} \mathrm{O}_{3}$, which is the final product of thermal decomposition. The mass loss calculated from TG curve is equal to $74,29 \%$ that corresponds to the $\mathrm{Ho}_{2} \mathrm{O}_{3}$ formation (calculated value is $75,73 \%$ ) The intermediate product of complex decomposition for at 573-912K is $\mathrm{HoOCl}$ The dehos tion formed at $573-912 \mathrm{~K}$ is $\mathrm{HoOCl}$. The dehydration process is connected with the endothermic effect seen in DTA curve, while the combustion of
the organic ligand is accompanied by exothermic one.

Considering the temperature at which the dehydration process of the complexes takes place, and the way by which it proceeds it is possible to assume that the water molecules may be in the outer sphere of complex coordination $[41,53-$ 55].

The IR and FIR spectra recorded for analysed compounds may also suggest that the molecules of water are probably bounded by hydrogen bond in outer-sphere of complex. The detailed data obtained from the determination of the complete structures of these complexes can give fai answer concerning above assumption. However their monocrystals have not been obtained so far, but attempts to obtain them have been made. The results indicate that the thermal decomposition of 4-chlorophenoxyacetates of $\mathrm{Nd}(\mathrm{HI}), \mathrm{Gd}(\mathrm{HI})$ and $\mathrm{Ho}(\mathrm{III})$ in air proceeds in the following way:

$\mathrm{LnL}_{3} \cdot \mathrm{nH}_{2} \mathrm{O} \rightarrow \mathrm{LnL}_{3} \rightarrow \mathrm{LnOCl} \rightarrow \mathrm{Ln}_{2} \mathrm{O}$ where $\mathrm{Ln}(\mathrm{III})=\mathrm{Nd}, \mathrm{Gd}, \mathrm{Ho}$ and $\mathrm{n}=2$ for $\mathrm{Nd}$ and $\mathrm{G}$ and $\mathrm{n}=3$ for $\mathrm{Ho}$

The values of enthalpy of dehydration process were determined with the use of DSC/TG system under nitrogen atmosphere. They are in the range of $156,80-90,81 \mathrm{~kJ} \cdot \mathrm{mol}^{-1}$ and $68,25-45,4$ $\mathrm{kJ} \cdot \mathrm{mol}^{-1}$ per one molecule of water. These value indicate that the water molecule is the strongest bounded in the Gd(HI) complex while that the weakest in $\mathrm{Nd}(\mathrm{III})$ compound. Taking into account

Ecl. Quím., São Paulo, 35(1): 67 - 75, 2010 the temperatures of dehydration process it appears that $\mathrm{Nd}(\mathrm{III})$ complex is the most thermally stable wile $\mathrm{Ho}(\mathrm{III})$ has the least thermal stability.

The solubility of analysed compounds (T) It is in the order of $10^{4}$ $\mathrm{mol} \cdot \mathrm{dm}^{-3}$. The $\mathrm{Ho}(\mathrm{HI})$ 4-chlorophenoxyacetate is mos soluble salt, while that of $\mathrm{N}(\mathrm{III})$ the ast solube one. These compound are hardly soluble in waser compounds are relatively astere sufficient to use 4-chlorophenoxyacetic acid for the separation of some metal ions by ion-exchange

The magnetic susceptibility of 4-chlorophenoxyacetates of $\mathrm{Nd}(\mathrm{III}), \mathrm{Gd}(\mathrm{III})$ and $\mathrm{Ho}$ (III) was measured over the range of 76-303K (Table 4). The values of the Weiss constant, $\theta$, for anlysed complexes were found to have a negative sig which probably arises from the antiferom spin interaction or from a crystal field splitting of the paramagnetic spin state [56-61]. The analysed mplexes obey the Curie-Weiss law.

The magnetic moment values experimentally determined at $76-303 \mathrm{~K}$ for $\mathrm{Nd}(\mathrm{III}), \mathrm{Gd}(\mathrm{III})$ and $\mathrm{Ho}(\mathrm{III})$ compounds change from 2,95 $\mu_{\mathrm{B}}$ (at $76 \mathrm{~K})$ to $3,47 \mu_{\mathrm{B}}$ (at $303 \mathrm{~K}$ ) for $\mathrm{Nd}(\mathrm{III})$ complex from $7,70 \mu$ (at $76 \mathrm{~K}$ ) to $7.82 \mu$ (at $303 \mathrm{~K}$ ) for Gd(III) G(III), and for

In 4-chlorophenoxyacetates of $\mathrm{Nd}(\mathrm{III})$ $\mathrm{Gd}(\mathrm{III})$ and $\mathrm{Ho}(\mathrm{III})$ the paramagnetic central ion remain practically unaffected by diamagnetic ligands coordinated around them. The f-electrons causing their paramagnetism are well separated from outside influences and they do not participate in the formation of M-O bond. They are an inner shell characterized by radius $0,35 \AA$ [ $[62]$ to be very small in comparison with the radius of the $5 \mathrm{~s}^{2} 5 \mathrm{p}^{6}$ closed shell ( $\sim 1 \AA$ ) Their energy levels are the same as in the free ions. For most of the lanthanide ions the ground state is separated by several hundred of $\mathrm{cm}^{-1}$ from the next higher lying state. Therefore the magnetic properties can be taken as those of the ground state alone. Taking into account this fact lanthanide ions in the compound act in the same way as the free ions. The values of $\mu_{\text {eff }}$ determined for 4-chlorophenoxyacetates are close to those calculated for $\mathrm{Ln}^{3+}$ ions by Hund and Van Vleck (Table 5). Their values at room temperature for analysed complexes are 
following: 3,74 $\mu_{\mathrm{B}}$ for $\mathrm{Nd}$; 7,23 $\mu_{\mathrm{B}}$ for Gd and References $10,60 \mu_{\mathrm{B}}$ for Ho [63].

From the values of magnetic moments deermined for the complexes it appears that energies of $4 f$ electrons in the central ions are not gies of 4 electrons in the centrions de ions. Thus, the colours of the complexes say de ions. Thus, the colours of the complexes stay the same as those in the free lanthanide ions. The electron density in the molecules makes the f-f electronic transitions of the central ions to be those of the lowest energy and the absorption occurs at relatively high wavelengths. The $4 \mathrm{f}$ orbitals of lanthanide ions effectively shielded by the $5 \mathrm{~s}^{2} 5 \mathrm{p}^{6}$ octet. Therefore the metal ligand bonding in lanre $[64,65]$.

\section{Conclusions}

On the basis of the results obtained it appears that 4-chlorophenoxyacetates of $\mathrm{Nd}$ (III), Gd(III), and Ho(III) were synthesized as hydrated complexes. Their colours are typical for the particular $\mathrm{Ln}(\mathrm{III})$ ion, i.e. violet for $\mathrm{Nd}$, white for $\mathrm{Gd}$, and cream for Ho, having their origin in the lowest energy of f-f electronic transitions of the central ions. Their energies are not radically changed in comparison with the free lanthanide ions, therefore the colours of the complexes are the same as those for the free lanthanide ions. The Ln-O band is mainly electrostatic in nature. The complexes are crystalline compounds that on heating in air to $1173 \mathrm{~K}$ decompose in three steps. In the first step they dehydrate to form anhydrous complexes that next decompose to the oxides of appropriate metals with intermediate formation of $\mathrm{LnOCl}$. The values of $\mu_{\text {eff }}$ calculated for the compounds ale close to those obtained for $\mathrm{Ln}^{3+}$ by Hund and Van Vleck. There is no influence of the ligand field of $4 \mathrm{f}$ electrons on lanthanide ions.

The solubilites of $\mathrm{Nd}(\mathrm{III}), \mathrm{Gd}(\mathrm{III})$ and $\mathrm{Ho}(\mathrm{III})$ 4-chlorophenoxyacetates in water at $293 \mathrm{~K}$ are of the order of $10^{-4} \mathrm{~mol}^{1} \cdot \mathrm{dm}^{-3}$.
[1] S.C. Mojumdar, D. Hudecova, and M. Melnik, Pol. J. Chem., 73 (1999)759

2] M. McCann, J.F. Cronin, and M. Devereux, Polyhedron, 17(1955)2379

[3] C.N. Rao, and S. Natarajan, Angew, Chem. Int. Ed, $43(2004) 1446$

[4] E.V. Dikarev, R,G, Gray, and B.Li, Angew. Chem. Int. Ed. 44(2005) 1721

5] L.Lewellyn, Jim - Ho Lee, Jong-San Chang, and G. Ferey, Angew. Chem. Int. Ed., 45 (2006) 8227

6] C.J. Kepert, T.J. Prior, and M.J. Rosseinsky, J. Sol. State Chem., 152 (2000) 261

[7] Y. Kim, and D.Y. Yung, Inorg. Chim. Acta, 338(2002)229 [8] Y. Bao-Hui, T. Ming-Liang, and Xiao-Ming Chem., Kord. Chem. Rev., 249(2005)545

[9] E.G. Palacios, and A.J. Monchemius, Hydrometallurgy, 62(2001)135

10] W.Ferenc, M.Bernat, J. Sarzyński, and B. Paszkowska, Ecl.Quim., São Paolo, 33(1): 7-14, 2008

11] Beilstein Handbuch der Organischen Chemie, Bd. VI/2, Springer Verlag, Berlin 1942

12] Frankin and Jones, American Chemical Paint Co, U.S 2.390, 941, Dec. 11.1945

13] K.N. Goswami, Z. Krist., 121(5), (1965), 400

[14] Kennard, Colin H.L., Smith, Graham, and White Allan.H.,

Acta Crystallorg., Sect.B 1981, B37(6), 1317-19

[15] S.Kumar, Vijay, and Rao Leela M., Acta Crystallogr.,

Sect. B. 1982 B 38(7), 2062

16] Denis, Janes C. Ramband Jerome, and Ger Offen 1.906,199, 11 Sept. 1969, Fr. Appl. 16 Feb. 1968

17] G. Plesch, M. Blahova, J. Kratsmar-Smogrovic, and S. urka, Z. Naturfors., B, 28, 1973, 521

18] W.Ferenc, A.Walków-Dziewulska, and S. Kuberski, hem. Pap., 57(5) (2003) 321-330

19] W.Ferenc, and B. Bocian, J. Them. Anal. Cal., 74(2003)

20] W.Ferenc, A.Walków-Dziewulska, and J. Sarzyński, Serb.Chem.Soc., 70(2005) 1075

[21] W.Ferenc, B. Cristóvão, and J. Sarzyński, J. Them. Anal. al., $86(2006) 783$

[22] W.Ferenc, A.Walków-Dziewulska, and J. Sarzyński, Ecl. Quim., São Paolo, 31(2) (2006) 17

23] W.Ferenc, A.Walków-Dziewulska, J. Sarzyński, and B. aszkowska, Ecl. Quim., são Paolo, 31(3) (2006) 7

W. Ferenc, A. Walkow-Dziewulska, J. Sarzyński, B. Pasz-

[25] K. Stępniak, W.Ferenc, B. Bocian, and T. Lis, Ecl. Quim.,

[26] W.Ferenc, A.Walków-Dziewulska, J. Sarzyński, and B. Paszkowska, J. Therm. Anal. Cal., 91 (2008) 285

[27] W.Ferenc, B. Cristóvão, J. Sarzyński, and B. Paszkowska, Ecl. Quim., São Paolo, 31(4) (2006) 7
[28] W.Ferenc, A.Walków-Dziewulska, and J. Sarzyński, Acta Chim. Slov. 54(2) (2007) 248

(29) W.Ferenc, K.Czapla, J. Sarzyński, and A. Zwolińska, Ecl. Quim., São Paolo, 33(2) (2008)

[30] W.Ferenc, K.Czapla, and J. Sarzyński, Ecl. Quim., São Paolo, 32(3) (2007) 7

[31] B.N. Figgs, and R.S. Nyholm, J. Chem. Soc., (1958) 4190

[32] E. König, Magnetic Properties of Coordination and O ganometallic Transition Metal Compounds., Springer Verlag, Berlin, 1966

[33] A. Bartecki, Electronic Spectra of Complex Compound. Scientific and Technical Publishers, Warsaw, 1987

34] A.E. Orgel, An Introduction to Transition - Metal Chenstry, Ligand-Field Theory. John Wiley and Sons, New York, 1960

[35] L.J. Bellamy, The Infrared Spectra of Complex Mo ecules, Chapman L. Hall Ltd, London, 1975

36] K. Nakamoto, Infrared and Raman Spectra of Inorganic and Coordination Compounds, John Wiley and Sons, Toronto,

37] A. Cross, and A.R. Jones, An Introduction to Practical Infrared Spectroscopy. Butterworths, London, 1969

38] R.C. Mehrotra and R. Bohra, Metal Carboxylates, Acrdemic Press, London. 1983

G.E. Walfaren, J.Chem. Phys., 40(1964)3249

40] W.A. Senior, and W.K. Thompson, Nature,

41] K. Burger, Coordination Chemistry: Experimental Meth-

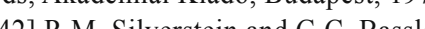

er, Spectrometric IdentiSompounds, Polish Scientific Publisher, Warsaw, 1970

[43] Y. Kim, and K. Machida, Spectrochim. Acta.

44] M. Mikami, I.Nakagawa, and T. Simanouchi, Spectrochim. Acta, 23A (1967)1037

45] K. Nakamoto, E. Udovich, and J. Takemoto, J.Am. c., $92(1970) 3973$
Richardson, W.F.

[46] M.F. Richardson, W.F. Wagner, and D.E. Sands, Inorg. Chem., 7(1968)2495

[47] R.C. Fay, and R.N. Lowry, Inorg. Nucl. Chem. Lett, (1967) 117

[48] W.D. Courier,
50 (1972) 1797

[49] A.K. Bridson, Inorganic Spectroscopic Metods, Oxford 50] L.M. Harw, New York, 1988

Jo L.M. Harwood, T.D. Claridge, Introduction to Organic [51] B.S. Manhas, and A.K. Trikha. J. Indin. Cho 1999 59(1982)315

[52] E. Łagiewka, and Z. Bojarski, X-Ray Structural Analysis, Polish Sientific Publisher, Warsaw, 1988
[53] A.V. Nikolaev, A.V. Logvinienko, and L.J. Myachina, Thermal Analysis Vol. 2. Academic Po, New York, [54] B. Singh, B. V. Agarwala, P.L. Mourya, and A.K. Dey, J. Indian Chem. Soc. 59 (1992)1130

[55] F. Paulik, Speciel Trends in Thermal Analysis, Wiley Chichester, 1995

[56] J. Mroziński, M. Janik, and T. Nowakowski, Scientic Numbers of Silesian Technical University, 119(1988)125 [57] A. Earnshaw, Introduction to Magnetochemistry, Academic Press, London, 1956

[58] E. O'Connor, Progress in Inorganic Chemistry, Wiley, New York, 1982

[59] F.A. Kettle, Inorganic Physical Chemistry, Polish Scientific Publisher, Warsaw, 1999

[60] J. Mroziński, Materials Science, Vol XIV (1988) [61] M.Hvastijova, M. Kochout, J. Mroziński, and J. Jäger, Polish J. Chem. 69(1995)852

[62] A.T.baker, A.M.Hammer, and S.E.Livingstone, Transi(1984)423

[63] L.H.Van Vleck, The Theory of Electronic and Magnetic Susceptibilities, Oxford University Press, Oxford, 1932

D. S.P.Sinha, Systematics and Properties of the Lanthanides, [65] D J.Kather J.Chem E D $47(1970) 424$ 